\title{
Evaluation of the Reliability of Computerized Profile Cephalometric Analysis
}

\author{
José Tarcísio Lima FERREIRA ${ }^{1}$ \\ Carlos de Souza TELLES ${ }^{2}$ \\ ${ }^{1}$ Department of Pediatric Dentistry, Faculty of Dentistry of Ribeirão Preto, USP, Ribeirão Preto, SP, Brazil \\ ${ }^{2}$ Department of Pediatric and Orthodontic Dentistry, Faculty of Dentistry, Federal University of Rio de Janeiro, \\ Rio de Janeiro, RJ, Brazil
}

\begin{abstract}
The use of computers as an auxiliary instrument for case evaluation and procedures in health sciences is not new, and their advantages are well known. A growing number of orthodontists are using computerized systems for cephalometric analysis. Thus, this study evaluated the reliability of both computerized and manual methods used for creating profile cephalograms. Fifty profile radiographs were selected from the files of the Post-Graduate Course in Orthodontics at the Dental School of the Federal University of Rio de Janeiro. The good quality of the material was the only necessary requirement for selection. Results were submitted to the interclass correlation coefficient and a reliable similarity between cephalometric data obtained through both evaluated methods was found. However, the clinical utilization of computerized cephalometric analysis is not absolutely reliable.
\end{abstract}

Key Words: cephalometry, computer, reliability.

\section{INTRODUCTION}

Concern with the quality offered by radiographs used in dental diagnostics is frequent and the factors that influence their final result begin with the exposure of the radiographic film to the $\mathrm{X}$ rays and end with the diagnostic process (1).

Despite the standardization offered by a teleradiograph after the cephalograph, many sources of errors are still involved in a cephalometric analysis. The main limitations are lack of precision in identifying points in a radiograph (2-4), double meaning of biological markers $(2,4,5)$, errors from the reading process $(6,7)$, and operator variability, which can interfere significantly in the reproducibility of measurements $(8,9)$.

From the positioning of the patient in the cephalograph to the use of computer hardware to group and measurement data, each step introduces a certain amount of error. The extent of these consecutive errors has a direct influence on the scientific and clinical reproducibility (reliability) of data interpretation (10). Thus, given the growing number of orthodontists using computer software for digital anatomical markers and cephalometric analysis (11), investigations are necessary regarding the use of the computer for this analysis. Therefore, this study evaluated a) the reliability of the computerized method without zoom in relation to the manual method for elaborating the profile cephalogram; b) the reliability of the computerized method with zoom in relation to the manual method for elaborating the profile cephalogram; c) if the computerized method with zoom was more accurate than without zoom; d) the possibility of the effective use of the computerized cephalogram in the clinic.

\section{MATERIAL AND METHODS}

The following materials were used: 50 profile cephalometric radiographs; one $0.5 \mathrm{~mm}$ propelling pencil; a UNITEK cephalometric kit; one cold light negatoscope; one black card paper; one 486 DX2 66 Mhz Compaq microcomputer; one BJ-200 Canon printer; one hundred sheets of Chamex paper for printing; RadioMemory Radiocef software (Belo Horizonte, MG, Brazil), version 1.9; one scanner HP Scanjet 4c; 13 formatted 1.44 MB TDK floppy disks. The computer- 
ized technique was evaluated with and without the use of the zoom and standard radiographic technique (12) was used for the manual method. The manual and computerized measurements were compared.

One operator drew each cephalogram manually, in random sequence, on an acetate sheet over each of the fifty teleradiographs. The same negatoscope, under ideal light conditions, was used. Light intensity was controlled using black card paper positioned as a mask over the radiographs, so that low contrast structures could be seen. When bilateral structures were present, only left ones were considered because of their reduced distortion.

Skeletal, dental and soft structures were demarcated on the cephalograms (Figure 1).

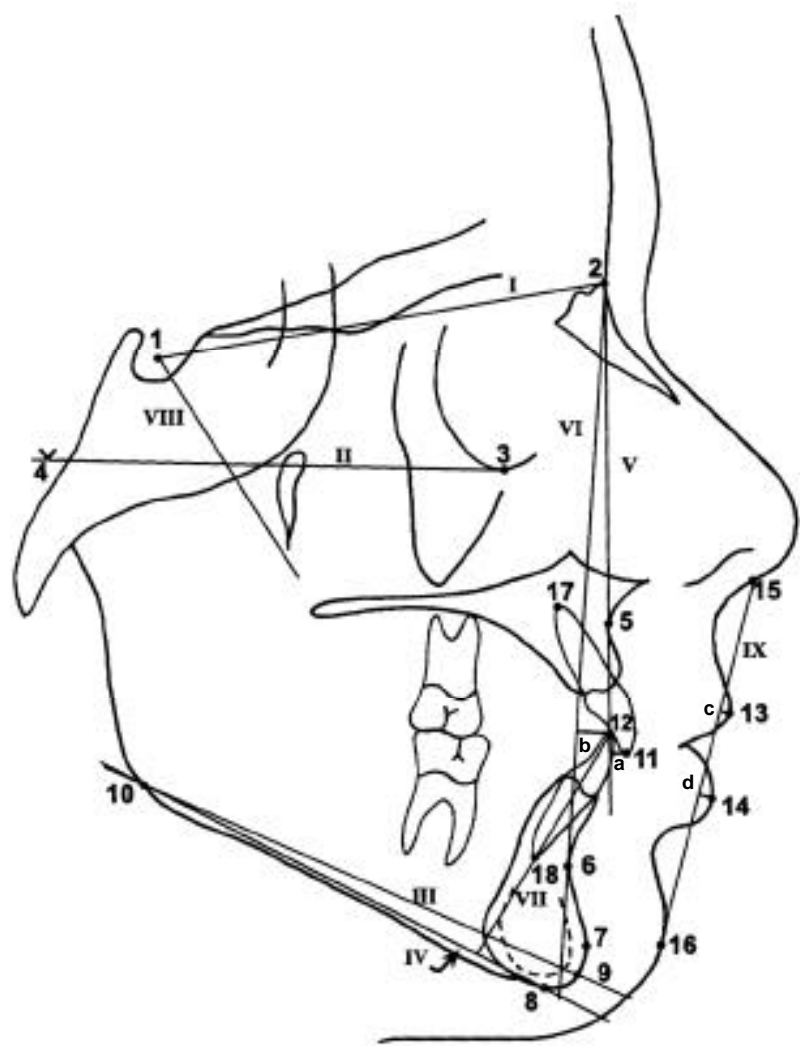

Figure 1. Lateral cephalometric tracing, constructed with the information regarding points, lines, planes, angular and linear segments utilized. Points: sella turcica (1), nasion (2), orbitale (3), porion (4), point A or subspinale (5), point B or supramentale (6), pogonion (7), menton (8), gnathion (9), gonion (10), upper incisal incision (11), lower incisal incision (12), upper lip (13), lower lip (14), point Prn or MN (15), soft tissue pogonion (16), upper incisive apex (17), and lower incisive apex (18). Lines and planes: sella-nasion line (I), Farnkfort's horizontal plane (II), Steiner's mandibular plane (III), Tweed's mandibular plane (IV), nasion-A line (V), nasion-B line (VI), lower central incisor axis (VII), sella turcica-gnathion line (VIII), and Steiner's aesthetic line (IX).
The following measurements were evaluated (Figure 1): i) angular measurements: SNA angle formed by the intersection of S-N (I) and N-A (V) lines; SNB angle - formed by the intersection of S-N (I) and N-B (VI) lines; NSGn angle - determined by the intersection of S-Gn (VIII) and SN (I) lines; GoGn-SN angle - determined by the intersection of the mandibular plane G-Gn (III) with the SN line (I); IMPA angle determined by the intersection of Tweed's mandibular plane and the axis of the lower central incisor (VII); ii) linear measurements: 1-NA - distance between the incisal border of the upper central incisor, more prominent, and the NA line (a); $\overline{1}-\mathrm{NB}$ - distance between the incisal border of the lower central incisor, more prominent, and the NB line (b); S-Ls - distance between the most prominent point of the upper lip and Steiner's $S$ line (c); S-Li - distance between the most prominent point of the lower lip and Steiner's $S$ line (d).

To evaluate intra-observer performance, five radiographs were randomly selected and manually and computerized traced (with and without zoom) twice, with a 15-day interval between evaluations. When the linear correlation test was performed, SNA angle measurements, with and without zoom, and linear measurements 1-NA, with and without zoom, were the only ones showing a correlation coefficient less then 0.7 . All other measurements presented coefficients greater than 0.9.

Statistical analysis was performed using an interclass correlation coefficient, evaluating the reliability within the same data class. Variability indices were determined for sampling (patients) and for each technique as well as a proportion of the total variability.

\section{RESULTS}

The results of the statistical analysis for angular and linear measurements from one manual and two computerized methods are presented in Tables 1 and 2 . In Table 1, the difference between manual and computerized measurements was evaluated. Considering coincident values, in both methods, approximately $1.0 \mathrm{de}$ gree for angular measurements and $1.0 \mathrm{~mm}$ for linear ones, it was possible to report: a) measurements SNA, NSGn, and IMPA showed better reliability in the computerized method with zoom than in the computerized method without zoom. Measurements GoGn-SN, S-Ls, and S-Li showed better reliability in the computerized method without zoom. There were no differences in the 
reliability of manual and computerized methods for all other measurements. b) Only the angular measurement IMPA showed a percentage below $50 \%$ for both computerized methods ( $38 \%$ without zoom; $42 \%$ with zoom). The angular measurement SNA represented $48 \%$ when the computerized method without zoom was compared to the manual one.

In Table 2, the interclass correlation coefficient for several measurements and between evaluations can be observed. Comparing the computerized method with- out zoom and the manual method, all measurements presented similarity over $80 \%$, except for linear measurement 1-NA (74.35\% reliability). Angular measurements SNA and IMPA, and linear measurement 1-NA had greater variation. Comparing the computerized method with zoom and the manual method, except for linear measurement 1-NA ( $76.23 \%$ reliability), the others presented similarity over $80 \%$. Angular measurements SNA and IMPA, and linear measurement $\underline{1-N A}$ had greater variation.
Table 1. Limit of variation of measurements.

\begin{tabular}{|c|c|c|c|c|}
\hline \multirow[t]{2}{*}{ Measurements } & \multicolumn{2}{|c|}{$\begin{array}{c}\text { Manual } \\
\mathrm{x} \\
\text { Comp. without zoom }\end{array}$} & \multicolumn{2}{|c|}{$\begin{array}{c}\text { Manual } \\
\mathrm{x} \\
\text { Comp. with zoom }\end{array}$} \\
\hline & Variation 1 & Variation 2 & Variation 1 & Variation 2 \\
\hline \multicolumn{5}{|c|}{ Angular measurements } \\
\hline SNA & 48 & 74 & 52 & 76 \\
\hline SNB & 62 & 76 & 62 & 78 \\
\hline NSGn & 76 & 86 & 78 & 86 \\
\hline GoGn-SN & 80 & 86 & 74 & 86 \\
\hline IMPA & 38 & 50 & 42 & 64 \\
\hline \multicolumn{5}{|c|}{ Linear measurements } \\
\hline$\underline{1}-\mathrm{NA}$ & 54 & 74 & 54 & 76 \\
\hline$\overline{1}-\mathrm{NB}$ & 98 & 100 & 98 & 100 \\
\hline S-Ls & 74.4 & 89.3 & 70.1 & 93.5 \\
\hline S-Li & 89.4 & 95.8 & 83 & 95.8 \\
\hline
\end{tabular}

Table 2. Interclass correlation coefficient for several measurements and between evaluations.

\begin{tabular}{lccc}
\hline Measurements & $\begin{array}{c}\text { Manual } \\
\text { x } \\
\text { Comp. without } \\
\text { zoom }\end{array}$ & $\begin{array}{c}\text { Manual } \\
\text { x } \\
\text { Comp. with } \\
\text { zoom }\end{array}$ & $\begin{array}{c}\text { Comp. without } \\
\text { zoom x } \\
\text { Comp. with } \\
\text { zoom }\end{array}$ \\
\hline Angular measurements & & & \\
SNA & 83.72 & 83.55 & 97.71 \\
SNB & 86.99 & 87.02 & 97.54 \\
NSGn & 88.68 & 88.54 & 97.48 \\
GoGn-SN & 94.78 & 94.57 & 99.15 \\
IMPA & 91.87 & 92.90 & 98.76 \\
& & & \\
Linear measurements & & & 97.32 \\
1-NA & 74.35 & 76.23 & 97.89 \\
1-NB & 96.79 & 97.36 & 95.82 \\
S-Ls & 81.31 & 83.50 & 96.99 \\
S-Li & 92.07 & 91.36 & \\
\hline
\end{tabular}

\section{DISCUSSION}

Because standardization is essential in comparative studies, procedures were performed by one operator. Manual tracing of all fifty radiographs was performed randomly, according to Houston (13). As for the sequence of the computerized methods, care was taken for each selected point to represent its manual correspondent. The identification process, in both manual and computerized methods, was performed with low luminosity and under the same conditions, as recommended by Houston (10).

Operator stress in conducting the cephalograms (14) was controlled by tracing all samples within 10 days, with 5 manual and 10 computerized tracings being conducted each day, as recommended by Salzmann (15).

Errors in cephalograms are common $(8,9)$ and can occur even with experienced operators (16). Comparative measurements are 5 times more precise than the individual identification of cephalometric points (17). Tracing replication is a good way of reducing bias $(2,5,13,14)$. The only uncontrolled source of error in this study was related to mechanical errors of the width of the pencil tip, since the software can be considered more precise in taking measurements.

In repeated identifications of a same reference point, errors have been found and their magnitude varies from one point to another (2). Even when repeated measurements are significantly different, a reliability over $75 \%$ can be considered good or excellent (11). The possibility of error in repetitively identifying 
points corresponds to approximately 1.0, with both angular and linear measurements presenting the same variation (4). If such limit is increased to around 2, it enhances the reliability of the measurements, as can be seen in Table 1 .

From positioning the patient in the cephalograph for taking the radiograph up to the use of the computer, each process introduces a certain amount of error (10). This was found in this study when S-Ls and S-Li measurements were analyzed. Even using all available resources for altering the computerized radiographic image those measurements could not be taken for 3 patients because of the lack of sharpness of the soft tissue profile, in both computerized methods.

We conclude that comparing the computerized method without zoom and the manual one, only measurement 1-NA showed reliability below $75 \%$; comparing the computerized method with zoom and the manual one all measurements showed reliability over $75 \%$; the computerized method with zoom was not more effective than the computerized method without zoom; despite the high interclass reliability obtained for the different methods, great variation was perceived. Therefore, the effective use of the computerized cephalogram in the clinic cannot be recommended as an absolutely reliable system.

\section{ACKNOWLEDGMENTS}

This research was supported by a grant from CAPES to Dr. J.T.L.Ferreira. Radiomemory kindly dontated the Radiocef software.

\section{RESUMO}

Ferreira JTL, Telles CS. Avaliação da confiabilidade da análise cefalométrica de perfil computadorizada. Braz Dent J 2002;13(3):201-204.

A utilização do computador como instrumento de auxílio na avaliação de casos e procedimentos na área da saúde não é novidade e vantagens do seu emprego têm, cada vez mais, se tornado aparente. Número crescente de ortodontistas tem adquirido sistema computadorizado para análises cefalométricas. Por isso este trabalho teve o propósito de avaliar a confiabilidade entre dois métodos utilizados na elaboração do cefalograma de perfil: o computadorizado e o manual. Foram selecionadas cinqüenta radiografias de perfil no arquivo do Curso de PósGraduação em Ortodontia da Faculdade de Odontologia da Universidade Federal do Rio de Janeiro. Boa qualidade do material foi única condição indispensável nesta seleção. Os resultados foram submetidos ao coeficiente de correlação intraclasse e semelhança confiável foi observada entre os dados cefalométricos obtidos a partir dos métodos empregados. Porém, não foi possível recomendar a utilização da cefalometria computadorizada como absolutamente confiável na clínica.

Unitermos: cefalometria, computador, confiabilidade.

\section{REFERENCES}

1. Rossmann K, Wiley BE. The central problem in the study of radiographic image quality. Radiol 1970;96:113-118.

2. Baumrind S, Frantz RC. The reliability of head film measurements. 1 - Landmark identification. Am J Orthod 1971;60:111-127.

3. Broch J, Slagsvold O, Rosler M. Error in landmark identification in lateral radiographic headplates. Eur J Orthod 1981;3:9-13.

4. Richardson A. An investigation into the reproducibility of some points, planes and lines used in cephalometric analysis. Am J Orthod 1966;52:637-651.

5. Midtgard J, Björk G, Linder Aronson S. Reproductibility of cephalometric landmarks and errors of measurements of cephalometric cranial distances. Angle Orthod 1974;44:56-61.

6. Cooke MS, Wei SH. Cephalometric errors: a comparison between repeat measurements and retaken radiographs. Aust Dent J 1991;36:38-43.

7. Thurow RC. Cephalometric methods in research and private practice. Angle Orthod 1951;21:104-116.

8. Albuquerque Jr HR, Almeida MHC. Avaliação do erro de reprodutibilidade dos valores cefalométricos aplicados na filosofia Tweed-Merrifield, pelos métodos computadorizado e convencional. Ortodontia 1998;31:18-30.

9. Stabrun AE, Danielsen K. Precision in cephalometric landmark identification. Eur J Orthod 1982;4:185-196.

10. Houston WJ. A comparison of the reliability of measurement of cephalometric radiographs by tracings and direct digitization. Swed Dent J 1982;15(Suppl):99-103.

11. Baskin HN, Cisneros GJ. A comparison of two computer cephalometric programs. J Clin Orthod 1997;31:231-233.

12. Broadbent BH. A new X-ray technique and its application to orthodontia. Angle Orthod 1931;1:45-66.

13. Houston WJB. The analysis of errors in orthodontic measurements. Am J Orthod 1983;83:382-390.

14. Sandler PJ. Reproducibility of cephalometric measurements. Br J Orthod 1988;15:105-110.

15. Salzmann JA. Limitations of roentgenographic cephalometrics. Am J Orthod 1964;50:169-188.

16. Martins LP, Santos-Pinto A, Martins JCR, Dias-Mendes A. Erro de reprodutibilidade das medidas cefalométricas das análises de Steiner e de Ricketts, pelo método convencional e pelo método computadorizado. Ortodontia 1995;28:4-16.

17. Hatton ME, Grainger RM. Reliability of measurements from cephalograms at the Burlington Orthodontic Research Centre. J Dent Res 1958;37:853-859.

18. Eriksen E, Solow B. Linearity of cephalometric digitizers. Eur J Orthod 1991;13:337-342.

19. Konchak PA, Koehler JA. A Pascal computer program for digitizing lateral cephalometric radiographs. Am J Orthod 1985;87:197200.

20. Lim KF, Foong KWC. Computed cephalometry - how reliable is it? J Dent Res 1997;76:1209 Abstract.

Accepted March 18, 2002 